\title{
Symposium review: Progesterone effects on early embryo development in cattle*
}

\author{
P. Lonergan† $\bullet$ and J. M. Sánchez $\bullet$ \\ School of Agriculture and Food Science, University College Dublin, Dublin 4, Ireland
}

\section{ABSTRACT}

The causes of low fertility in dairy cattle are complex and multifactorial and may be due to compromised follicle development affecting oocyte quality, a suboptimal reproductive tract environment incapable of supporting normal embryo development, or a combination of both. Progesterone (P4) plays a key role in reproductive events associated with establishment and maintenance of pregnancy, through its effects on oocyte quality and its action on the uterine endometrium. Reduced P4 concentrations during growth of the ovulatory follicle are associated with lower fertility, and low concentrations of circulating P4 after ovulation have been associated with reductions in conceptus growth and elongation, decreased interferon- $\tau$ (IFNT) production, and lower pregnancy rates in cattle. In contrast, elevated concentrations of circulating $\mathrm{P} 4$ in the period immediately following conception have been associated with advancement of conceptus elongation, increased IFNT production, and, in some cases, higher pregnancy rates in cattle. Despite the potential beneficial effects of exogenous $\mathrm{P} 4$ supplementation on fertility, results of supplementation studies have been inconsistent. As part of the 2019 ADSA Reproduction Symposium, focusing on the etiology of pregnancy losses in dairy cattle, the aim of this review is to highlight recent findings from our group and others in relation to embryo-maternal interaction during bovine pregnancy establishment and the role of P4 in uterine biology and embryo development.

Key words: pregnancy, dairy cow, embryo-maternal communication

Received March 24, 2020.

Accepted April 29, 2020.

*Presented as part of the Reproduction Symposium: The Etiology of Pregnancy Failure in Cattle - The When and Why at the ADSA Annual Meeting, Cincinnati, Ohio, June 2019.

†Corresponding author: pat.lonergan@ucd.ie

\section{INTRODUCTION}

In dairy production, fertility is one of the main drivers of herd profitability through its effects in achieving greater production and maintaining short calving intervals (De Vries 2006). This is particularly true of seasonal systems with short, well-defined breeding periods, where calving pattern (driven by submission rate and conception rate) is a key driver of profitability (Shalloo et al., 2014). Improved management practices and genetic selection have contributed to reversal of negative trends in dairy cow fertility associated with past selection focused solely on increased production (Carvalho et al., 2018; Cole and VanRaden, 2018; Lucy 2019), but further progress is still required. Today, none of the modern selection indexes used globally are based solely on milk fat and protein production; milk production traits typically comprise approximately $50 \%$ of the total index, with the remainder comprising fertility, calving, beef, maintenance, management, and health traits (Miglior et al., 2017; Cole and VanRaden, 2018).

Successful pregnancy establishment involves ovulation of a competent oocyte, fertilization by a capacitated sperm, and growth of the embryo in an environment conducive to normal development. Following fertilization, the bovine embryo enters the uterus at about the 16-cell stage on approximately d 4 of pregnancy. By d 7, the embryo has formed a blastocyst consisting of an inner cell mass, which, after further differentiation, gives rise to the embryo, and the trophectoderm, which ultimately forms the placenta. After hatching from the zona pellucida on d 9 to 10, the blastocyst begins to grow and change in morphology from a spherical to ovoid shape during a transitory phase preceding the elongation or outgrowth of the trophectoderm to a filamentous form that usually begins between d 12 and 14. Around this time, the trophectoderm cells of the conceptus begin to secrete significant amounts of interferon- $\boldsymbol{\tau}$ (IFNT), the pregnancy recognition factor in cattle, which abrogates the uterine luteolytic mechanism to ensure maintenance of a functional corpus luteum (CL) for production of progesterone (P4; Forde and Lonergan, 2017). The developing bovine conceptus 
is dependent on maternally derived factors present in the uterine luminal fluid (ULF) for its growth and development beyond the zona-enclosed blastocyst stage. In particular, these maternally derived factors, perhaps in conjunction with the physical nature of the reproductive tract, drive elongation of the conceptus.

Although fertilization success is typically high $(>85 \%)$ following $\mathrm{AI}$ in cattle, many of the resulting embryos fail to develop to term. A significant proportion of this loss occurs between fertilization and maternal recognition of pregnancy (Diskin and Morris, 2008; Berg et al., 2010), which in cattle occurs around d 16 after estrus; indeed, in high-producing dairy cows, as many as 50\% of embryos are no longer viable by d 7 (Sartori et al., 2010; Wiltbank et al., 2016).

The success of in vitro fertilization demonstrates that contact with the female reproductive tract is not necessary for the embryo to reach the hatched blastocyst stage. However, the characteristic elongation of the conceptus before implantation is dependent on secretions from the uterus, as evidenced by the fact that it does not occur in vitro (Fléchon et al., 1986) and does not occur in vivo in the absence of uterine glands (Gray et al., 2001). These approaches highlight the key role of the uterine endometrium in driving the elongation process via endometrial secretions that compose the ULF, or histotroph. Spatial and temporal changes of the endometrial transcriptome and histotroph composition are necessary to establish uterine receptivity to implantation and, in turn, are pivotal to the success of pregnancy establishment. These modifications are regulated by conceptus-derived IFNT together with maternally derived P4 from the CL, to induce expression of genes in uterine luminal epithelium (LE) and superficial glandular epithelium (GE) for transport and secretion of histotroph into the uterine lumen to support growth and development of the conceptus.

Circulating concentrations of $\mathrm{P} 4$ represent a balance between production and metabolism of P4 (Wiltbank et al., 2014). Production of $\mathrm{P} 4$ is regulated by the development of the CL after the LH surge and ovulation, the number of granulosa cells that luteinize into large luteal cells (Niswender, 2002), and constitutive production of $\mathrm{P} 4$ by the large luteal cells. Metabolism of P4 is related to the blood flow to the liver, due to the abundance in the bovine liver of enzymes that mediate metabolism of P4 (Sangsritavong et al., 2002; Wiltbank et al., 2014). Various methods to elevate P4 during growth of the preovulatory follicle have been shown to increase pregnancy per AI and reduce double ovulation, thus improving fertility in lactating dairy cows (Wiltbank et al., 2014). Low circulating concentrations of P4 near AI, indicative of optimal CL regression, are required to optimize fertility, and elevated $\mathrm{P} 4$ concentrations after
AI can influence embryonic development and may, in some circumstances, improve fertility (Wiltbank et al., 2014; Yan et al., 2016). Thus, strategies to optimize P4 concentrations during selected reproductive periods may improve reproductive efficiency of lactating dairy cows.

As part of the 2019 ADSA Reproduction Symposium, focusing on the etiology of pregnancy losses in dairy cattle, the aim of this review is to highlight recent findings from our group and others in relation to embryomaternal interaction during pregnancy establishment in cattle and the role of P4 in uterine biology and embryo development. The role of $\mathrm{P} 4$ in preovulatory follicle growth, conceptus development, and uterine receptivity has been the subject of numerous comprehensive reviews; rather than repeat in detail what has already been written, the reader is directed to several other comprehensive reviews on the subject (Inskeep 2004; Lonergan 2011; Wiltbank et al., 2014; Lonergan and Forde, 2015; Spencer et al., 2016; Yan et al., 2016).

\section{PROGESTERONE AND OOCYTE QUALITY}

High P4 concentrations during the growth of the ovulatory follicle are associated with improved oocyte quality and pregnancy outcomes. During the final period of follicle growth, between the preovulatory LH surge and ovulation, the follicular fluid changes from an environment dominated by estradiol to one that is dominated by P4 (Dieleman et al., 1983) as the granulosa cells luteinize in preparation for the formation of the CL after ovulation. Whether these changes in the follicle have a direct influence on the oocyte is unclear, but given that this is coincident with resumption of meiosis and maturation of the oocyte, a role in determining oocyte quality is likely. Interestingly, injection of bovine preovulatory follicles with trilostane, an inhibitor of 3 $\beta$-hydroxysteroid dehydrogenase, an enzyme that catalyzes the synthesis of $\mathrm{P} 4$ from pregnenolone (to block the preovulatory rise in intrafollicular $\mathrm{P} 4$ ), resulted in a significant decline in $\mathrm{P} 4$ production in the follicle but did not affect ovulation rate or CL function as determined by serum P4 on d 1 to 9 of the subsequent luteal phase (Li et al., 2007). Unfortunately, oocyte quality was not assessed in that study. However, inhibition of $\mathrm{P} 4$ synthesis by cumulus cells in vitro resulted in a decrease in bovine embryo development, indicating that P4 intracellular signaling is important for oocyte developmental competence (Aparicio et al., 2011).

The role of elevated P4 before AI during the growth of the preovulatory follicular wave in optimizing fertility has been well reviewed (Pursley and Martins, 2011; Wiltbank et al., 2011, 2014; Bisinotto et al., 2015). Reduced $\mathrm{P} 4$ concentrations during growth of the first fol- 
licular wave affects embryo quality after superstimulation (Nasser et al., 2011; Rivera et al., 2011) and reduces pregnancy per AI of lactating dairy cows (Denicol et al., 2012); in both cases, outcomes were improved with supplemental P4. Based on such studies, sophisticated hormonal synchronization protocols based on Ovsynch modifications such as G6G or Double-Ovsynch have been widely incorporated into reproductive management programs by dairy farmers, particularly in the United States (Carvalho et al., 2018).

\section{PROGESTERONE AND THE OVIDUCT/EARLY EMBRYO}

In the cow, circulating $\mathrm{P} 4$ concentrations begin to increase to detectable levels from about d 3 after onset of estrus, at which stage the embryo is still in the oviduct. Exogenous P4 administered to pregnant cattle before this time accelerated transport of the embryo into the uterus (Crisman et al., 1980). Furthermore, transfer of embryos into an asynchronous (advanced) oviduct resulted in accelerated transport to the uterus (Rodríguez-Alonso et al., 2020). Hugentobler et al. (2010) characterized the effects of changes in systemic P4 (achieved by infusion of P4) on amino acid, ion, and energy substrate composition of oviduct and uterine fluids on $\mathrm{d} 3$ and 6 , respectively, of the estrous cycle in cattle. Progesterone increased uterine glucose and decreased oviduct sulfate and, to a lesser degree, oviduct sodium, but had no effect on any of the ions in the uterus. The most marked effect of P4 was on oviductal amino acid concentrations; 9 of 20 amino acids increased following supplementation, with glycine showing the largest increase of approximately 2-fold, whereas in the uterus only valine was increased. SaintDizier et al. (2012) described expression of nuclear P4 receptor (PGR) and P4 receptor membrane components 1 and 2 in the oviduct of cyclic and pregnant cows during the post-ovulation period, suggesting that $\mathrm{P} 4$ regulates the functions of the bovine oviduct in a region-specific manner and through both classical and nonclassical pathways during the post-ovulation period. Bylander et al. (2015) reported that P4 regulates the expression of endothelin 1 and endothelin receptor A in the mouse oviduct, which, together with previous studies of the effects of endothelin on muscular contractions in the oviduct, suggests that endothelin is a mediator of the P4-controlled effects on muscular contraction and eventually gamete transport in the fallopian tube. A large number of genes are affected in PGR knockout mouse oviducts during the periovulatory period that may have a role in oocyte capture and transport after ovulation (Akison and Robker 2012).
Overall, little convincing evidence exists for a direct effect of P4 on the early embryo. In our own laboratory, culture of embryos in vitro in the presence of $\mathrm{P} 4$ did not affect the proportion developing to the blastocyst stage in the presence or absence of oviductal epithelial cells (Clemente et al., 2009). This finding is consistent with the observations of Larson et al. (2011), who failed to observe a direct effect of $\mathrm{P} 4$ from either $\mathrm{d} 1$ to 3 or $\mathrm{d} 4$ to 7 after fertilization. Furthermore, addition of P4 to culture medium had no effect on conceptus elongation after transfer to synchronized recipients (Clemente et al., 2009). In a study by Carter et al. (2008), no differences in embryo development on d 5 or 7 were observed when beef heifers were supplemented with exogenous P4 from d 3, despite dramatic effects on post-hatching elongation between d 13 and 16 of pregnancy. A followup study found no effect of $\mathrm{P} 4$ on the proportion of embryos that developed to the blastocyst stage by $\mathrm{d} 7$ following transfer of multiple in vitro produced embryos (zygotes) to the oviduct of beef heifers that did or did not receive supplemental $\mathrm{P} 4$ insert from d 3 after onset of estrus (Carter et al., 2010). However, changes in the transcriptome of embryos collected from heifers with elevated P4 were observed, which may be associated with advanced elongation post-hatching.

\section{PROGESTERONE AND THE ENDOMETRIUM}

A prerequisite for establishing uterine receptivity to implantation in all species studied thus far is loss of expression of PGR from uterine LE and then GE (Bazer et al., 2010). Paradoxically, it is sustained exposure of the endometrium to circulating concentrations of $\mathrm{P} 4$ that leads to this downregulation of PGR as the luteal phase of the estrous cycle progresses. The concentration of $\mathrm{P} 4$ in circulation regulates expression of PGR in the endometrium such that, in animals with high P4, early loss of the PGR occurs (Okumu et al., 2010) - that is, uterine receptivity to implantation is established earlier. Conversely, low or suboptimal concentrations of $\mathrm{P} 4$ delay loss of the PGR and thus delay establishment of uterine receptivity to implantation (Forde et al. 2011a).

The transcriptome of the cyclic and pregnant bovine endometrium has been described by several authors under a variety of experimental conditions (Forde et al., 2009, 2011a,b, 2012; Bauersachs et al., 2012; Binelli et al., 2015; Sánchez et al., 2019a,b). It is clear that temporal changes in endometrial gene expression occur irrespective of whether the cow is pregnant, and it is really only at the time of maternal recognition of pregnancy at around d 16 that major changes in gene expression are detectable between pregnant and cyclic animals (Forde et al. 2011b; Bauersachs et al., 
2012). An adequate rise in P4 after ovulation drives these normal temporal changes in the endometrial transcriptome of cattle, which are necessary for the establishment of uterine receptivity and the promotion of conceptus development. Forde et al. (2009) described the global transcriptome of the endometrium from $\mathrm{d} 5$ to 16 in pregnant and cyclic cattle under conditions of normal and elevated $\mathrm{P} 4$, and revealed how circulating concentrations of $\mathrm{P} 4$ regulate endometrial genes. Their study found that $\mathrm{P} 4$ supplementation advances the normal temporal changes in endometrial gene expression, particularly for genes associated with energy sources or contributors to histotroph, which may contribute to advanced conceptus development on d 13 and 16 .

Successful pregnancy establishment and maintenance depends on the precise modulation of the maternal immune system to create a receptive and embryotrophic environment for the development of the semi-allogenic conceptus (see reviews by Fair, 2015; Szekeres-Bartho, 2018; Ott, 2020). Progesterone is known to modulate immune function in the uterus, and increasing evidence suggests that these effects may extend to peripheral blood (Oliveira and Hansen, 2008). In particular, progesterone can block allograft (Hansen et al., 1986; Padua et al., 2005) and xenograft (Majewski and Hansen 2002) rejection (reviewed by Hansen 2010). Indeed, many of the genes differentially expressed by elevated progesterone are related to the immune system and are associated with positive regulation of inflammatory response, immune response, and embryo implantation (Forde et al., 2009).

\section{PROGESTERONE AND UTERINE FLUID COMPOSITION}

The ULF contains embryotrophic substances, collectively termed histotroph, that drive elongation of the conceptus via effects on trophectoderm proliferation and migration as well as attachment and adhesion to the endometrial LE (Bazer et al., 2010). The ULF is derived primarily from transport or synthesis and secretion of substances by the LE and GE, but also the conceptus, and it is a complex and rather undefined mixture of proteins, lipids, amino acids, sugars (glucose, fructose), ions, and exosomes or microvesicles. Progesterone induces the expression of several genes in the endometrial epithelium that are then further stimulated by factors from the conceptus (e.g., IFNT and prostaglandins) and the endometrium itself (Dorniak et al., 2013; Brooks et al., 2014; Lonergan and Forde 2014). In turn, the genes and functions regulated by these hormones and factors in the endometrial epithelia cause specific changes in the uterine histotroph that govern conceptus survival and elongation (Faulkner et al., 2013; Forde et al., 2014, 2015). The composition of ULF during the preimplantation period has been extensively studied in sheep (see review by Bazer et al., 2015, and references therein). Data in cattle are more limited, although various studies have reported on aspects of ULF composition under various physiological states (Mullen et al., 2012; Faulkner et al., 2013; Forde et al., 2015). Expression of several proteins on d 7 and 15 of the cycle has been correlated with $\mathrm{P} 4$ concentrations during d 3 to 7 (Faulkner et al., 2013), some of which had been previously shown to be differentially expressed between d 7 and 13 of the estrous cycle (Mullen et al., 2012).

In a series of recent studies, we described the metabolic characteristics of ULF on d 12 to 14 - the period around the initiation of conceptus elongation in cattle -from cyclic heifers supplemented or not with P4 on d 3 after estrus. Over 5,000 metabolites were screened for by high-throughput untargeted ultrahigh-performance liquid chromatography tandem mass spectroscopy, with 233 consistently identified, clustering within 8 superpathways: amino acids, carbohydrates (Simintiras et al., 2019c), lipids (Simintiras et al., 2019a), cofactors, vitamins, nucleotides, peptides, energy substrates, and xenobiotics (Simintiras et al., 2019b). Fructose and mannitol/sorbitol were elevated by 18.4 and 28.4 -fold, respectively, in the ULF of high versus normal P4 heifers on d 12 (Simintiras et al., 2019c), suggestive of a key role for these metabolites in sustaining, in addition to initiating, conceptus elongation. Consistent with these observations, one of the proteins with very high abundance alteration between high-fertility and low-fertility heifers was sorbitol dehydrogenase, with14.3- and 11.1-fold increases in highfertility Holstein and Montbéliarde heifers compared with low-fertility Holsteins, respectively (Gegenfurtner et al., 2020). Sorbitol dehydrogenase, which is known to be located in the extracellular space, is required for the conversion of glucose to fructose by oxidation of sorbitol and has been shown to be expressed in porcine GE and LE during the peri-implantation period (Steinhauser et al., 2016).

\section{PROGESTERONE AND CONCEPTUS ELONGATION}

Elongation of the ruminant conceptus is essential for normal pregnancy recognition and implantation. Fléchon et al. (1986) cut d-12 ovine conceptuses into pieces and cultured them in vitro for $24 \mathrm{~h}$, to produce structures called trophoblastic vesicles (TV, conceptuses without the embryonic disk). Such TV survived in vitro for up to $10 \mathrm{~d}$ but failed to elongate. In contrast, TV elongated in vivo after transfer to recipients, demonstrating that trophoblast elongation does not depend 
necessarily on the presence of the embryo proper but can occur in TV composed only of the trophectoderm and the extraembryonic endoderm.

The effects of elevated P4 shortly after conception on the advancement of conceptus elongation have been convincingly demonstrated in cattle and sheep. Garrett et al. (1988) administered $100 \mathrm{mg}$ of $\mathrm{P} 4$ on d 1, 2, 3, and 4 of pregnancy, which increased concentrations of P4 in peripheral plasma on d 2 to 5 and significantly larger conceptuses on d 14. Using a P4 implant on d 3 of pregnancy, Carter et al. (2008) elevated concentrations of $\mathrm{P} 4$ in plasma until $\mathrm{d} 8$, and this was associated with larger conceptuses recovered at slaughter on d 16. Similarly, when ewes received daily injections of $25 \mathrm{mg}$ of $\mathrm{P} 4$ from $36 \mathrm{~h}$ after mating, blastocyst diameter increased by $220 \%$ on $\mathrm{d} 9$, and the time of initiation of elongation of blastocysts to a filamentous conceptus on d 12 was advanced (Satterfield et al., 2006); these effects of P4 treatment on blastocyst development were blocked by administration of RU486, a PGR antagonist.

Using a combination of in vitro embryo production and in vivo embryo transfer techniques, we have shown that the effect of $\mathrm{P} 4$ on conceptus development is mediated exclusively via the endometrium (Clemente et al., 2009). Interestingly, the embryo does not need to be present in the uterus during the period of $\mathrm{P} 4$ elevation to benefit from it (Clemente et al., 2009), strongly suggesting that the effect of $\mathrm{P} 4$ is via advancement of the normal temporal changes that occur in the endometrial transcriptome (Forde et al., 2009), resulting in advanced conceptus elongation. In addition, reducing the output of $\mathrm{P} 4$ from the CL-for example, by treatment with prostaglandin $\mathrm{F}_{2 \alpha}$ (Beltman et al., 2009; Forde et al., 2011a, 2012) or by aspirating the contents of the preovulatory follicle just before the expected time of ovulation (O'Hara et al., 2012) - results in a delay in the temporal changes in the endometrial transcriptome and reduced ability to support conceptus elongation in vivo.

In another attempt to understand the effect of an early elevation of $\mathrm{P} 4$ concentrations on embryo elongation, avoiding the potential effects of administration of exogenous hormones used in the previously mentioned studies, we designed a model comparing the ability of the ipsilateral and contralateral uterine horns to support preimplantation conceptus survival and growth to d 14 (Sánchez et al., 2019b). This approach is based on data from embryo transfer studies that indicate that transfer to the contralateral uterine horn relative to the CL reduces pregnancy rate (Christie et al., 1979; Del Campo et al., 1983) and that P4 concentrations in the tip of this horn are lower than in the ipsilateral horn (Pope et al., 1982; Takahashi et al., 2016). Although we found differences in gene expression between the endometrium of uterine horns ipsilateral and contralateral to the CL in cattle, they did not influence conceptus survival between $\mathrm{d} 7$ and 14 or conceptus length at $\mathrm{d}$ 14.

Considerable variation exists in the lengths of conceptuses recovered on the same day, even when recovered from the same uterus, following the transfer of multiple (up to 20) d-7 blastocysts. This suggests that at least some of the variation is independent of $\mathrm{P} 4$ concentrations. Conceptus length on a given day in the period around pregnancy recognition is thought to be indicative of its quality and the likelihood of establishing and maintaining a pregnancy (Barnwell et al., 2016), although this has yet to be definitively established. Barnwell et al. (2016) reported significant differences in the transcriptomes of long (mean $\pm \mathrm{SE} ; 24.7 \pm 1.9$ $\mathrm{mm}$ ) and short $(4.2 \pm 0.1 \mathrm{~mm}) \mathrm{d}-15$ conceptuses largely involved in metabolic and biosynthetic processes and the immune response. Interestingly, long and short conceptuses also displayed distinct regulation of genes previously associated with developmental competency to term and enhanced elongation. Furthermore, such age-matched conceptuses of different lengths elicit different responses from the endometrium in terms of gene expression, in an IFNT-dependent and independent manner, which may be important for optimal maternal recognition of pregnancy (Sánchez et al., 2019a).

In an effort to explain the variation in conceptus size seen on d 15 following bulk transfer of embryos on d 7 , Shorten et al. (2018) modeled the interaction between blastocyst developmental stage and P4-stimulated uterine factors on conceptus development on d 15. The model determined that if the embryo develops to blastocyst stage, the uterine environment, driven by $\mathrm{P} 4$, is a more important component than blastocyst size in the stimulation of embryonic growth rate to ensure adequate IFNT for pregnancy recognition. Expression of 6 trophectoderm genes (IFNT, TKDP1, PAG11, PTGS2, DKK1, and PDPN) was correlated with conceptus length.

\section{ASYNCHRONOUS EMBRYO TRANSFER}

The regulatory effect of the uterus on bovine conceptus development and the role played by $\mathrm{P} 4$ are nicely illustrated in studies comparing the outcomes of synchronous and asynchronous embryo transfer. Administration of $\mathrm{P} 4$ early in the estrous cycle of the recipient has been shown in some cases to effectively advance uterine receptivity for the transfer of older asynchronous embryos. In sheep, d-6 recipients after early exposure to exogenous P4 supported development of 
transferred d-10 blastocysts (Lawson and Cahill 1983). Asynchronous transfer of $\mathrm{d}-7$ bovine blastocysts to the uteri of d-5 or d-9 recipients resulted in delayed (5.4 \pm $0.4 \mathrm{~mm})$ or advanced $(50.4 \pm 5.2 \mathrm{~mm})$ conceptuses on d 14, respectively, compared with synchronous controls (d 7 to $\mathrm{d}$ 7: $15.7 \pm 1.5 \mathrm{~mm}$ ) or conceptuses derived from AI (12.0 $\pm 3.3 \mathrm{~mm}$; Ledgard et al. 2012). Consistent with these observations, Geisert et al. (1991) reported that only 1 of 21 (4.8\%) d-8 bovine blastocysts transferred to a d- 5 uterus established pregnancy, compared with $50 \%$ in synchronous controls.

Similar data have been reported recently by Randi et al. (2016), who transferred multiple d-7 bovine blastocysts to synchronous (d-7) or asynchronous (d-5 or d-9) recipients ( $\mathrm{n}=10$ per recipient). Transfer of $\mathrm{d}-7$ blastocysts to a d-5 uterus resulted in fewer conceptuses surviving (20\%) and delayed elongation in those that were recovered. In contrast, transfer to an advanced d-9 uterine environment resulted in the same level of survival as synchronous controls (approximately 50\%), but conceptus elongation was markedly advanced, in agreement with the observations of Ledgard et al. (2012). Supplementation of d-5 recipients with exogenous P4 from d 3 increased circulating concentrations of P4 and, subsequently, conceptus length compared with d-5 controls; however, early supplementation with exogenous $\mathrm{P} 4$ reduced the length of estrous cycles in approximately $50 \%$ of heifers, as will be further discussed.

Despite these positive effects on conceptus elongation, interrogation of data from commercial embryo transfer operations indicates that pregnancy is reduced if close synchrony is not assured. For example, in the study of Randi et al. (2016), transfer of a d-7 blastocyst to a d- 5 $(40.8 \%)$ or a d-8 (41.3\%) uterus moderately influenced pregnancy rate, whereas transfer to a uterus $2 \mathrm{~d}$ in advance (d 9: $24.4 \%$ ) or $3 \mathrm{~d}$ behind (d 4:27.0\%) dramatically reduced pregnancy rates compared with results from synchronous transfer of blastocysts. Taking the results of all of these studies together, it is clear that the accelerated conceptus elongation associated with transfer of a blastocyst to an advanced uterus does not necessarily translate into an improved pregnancy rate; rather, once synchrony is exceeded by approximately 48 $\mathrm{h}$, pregnancy rates decline appreciably.

\section{STRATEGIES TO INCREASE P4 FOLLOWING AI}

Many studies have attempted to improve fertility by elevating P4 after timed AI. Approaches taken to increase peripheral concentrations of $\mathrm{P} 4$ after AI include those that (1) increase function of the existing CL (e.g., strategies that promote growth of the dominant follicle before ovulation, resulting in a larger CL, or luteotrophic treatments, which stimulate CL development, such as administration of human chorionic gonadotropin (hCG; Sánchez et al., 2018); (2) those that induce ovulation of a dominant follicle and formation of accessory CL (e.g., hCG or GnRH administration; Nascimento et al., 2013; Niles et al., 2019); or (3) those that supplement progesterone directly (e.g., via injection or intravaginal devices; Geisert et al., 1991; see Figure 1). However, data on outcome in terms of pregnancy rate are often conflicting or inconclusive. A recent meta-analysis concluded that P4 supplementation was beneficial only in cows of lower fertility and only after natural estrus, and that the benefits required exogenous $\mathrm{P} 4$ supplementation to begin between d 3 and 7 (Yan et al., 2016). Thus, although a significant volume of research has provided insight into the mechanisms regulating circulating $\mathrm{P} 4$ concentrations and actions on the uterus and conceptus, more research is required to best understand how P4 manipulation can be repeatedly used to improve reproductive success.

\section{CONCLUSIONS}

Low P4 concentrations have been implicated as a causative factor in low pregnancy rates observed in high-yielding dairy cows. Although direct effects of P4 on the early pre-hatched embryo have not been convincingly demonstrated, elevated concentrations of $\mathrm{P} 4$ in the period immediately following conception have been associated with an advancement of conceptus elongation, an increase in IFNT production, and higher pregnancy rates in cattle. Elevated P4 advances the transcriptomic changes in the endometrium that normally occur during pregnancy, resulting in enhanced conceptus elongation. Interestingly, the embryo does not have to be present in the uterus during the period of $\mathrm{P} 4$ elevation to benefit from it, supporting the concept that the positive effect on conceptus growth is mediated via $\mathrm{P} 4$-induced changes in the endometrial transcriptome. Innovative strategies aimed at optimizing circulating concentrations of $\mathrm{P} 4$ following conception have the potential to improve embryo survival in cattle. However, many studies have attempted to improve fertility by elevating P4 after AI, with only marginal elevations in fertility.

\section{ACKNOWLEDGMENTS}

The authors' work is funded by Science Foundation Ireland (13/IA/1983; Dublin) and the Irish Department of Agriculture, Food and The Marine (13S528; Dublin). The authors have not stated any conflicts of interest. 


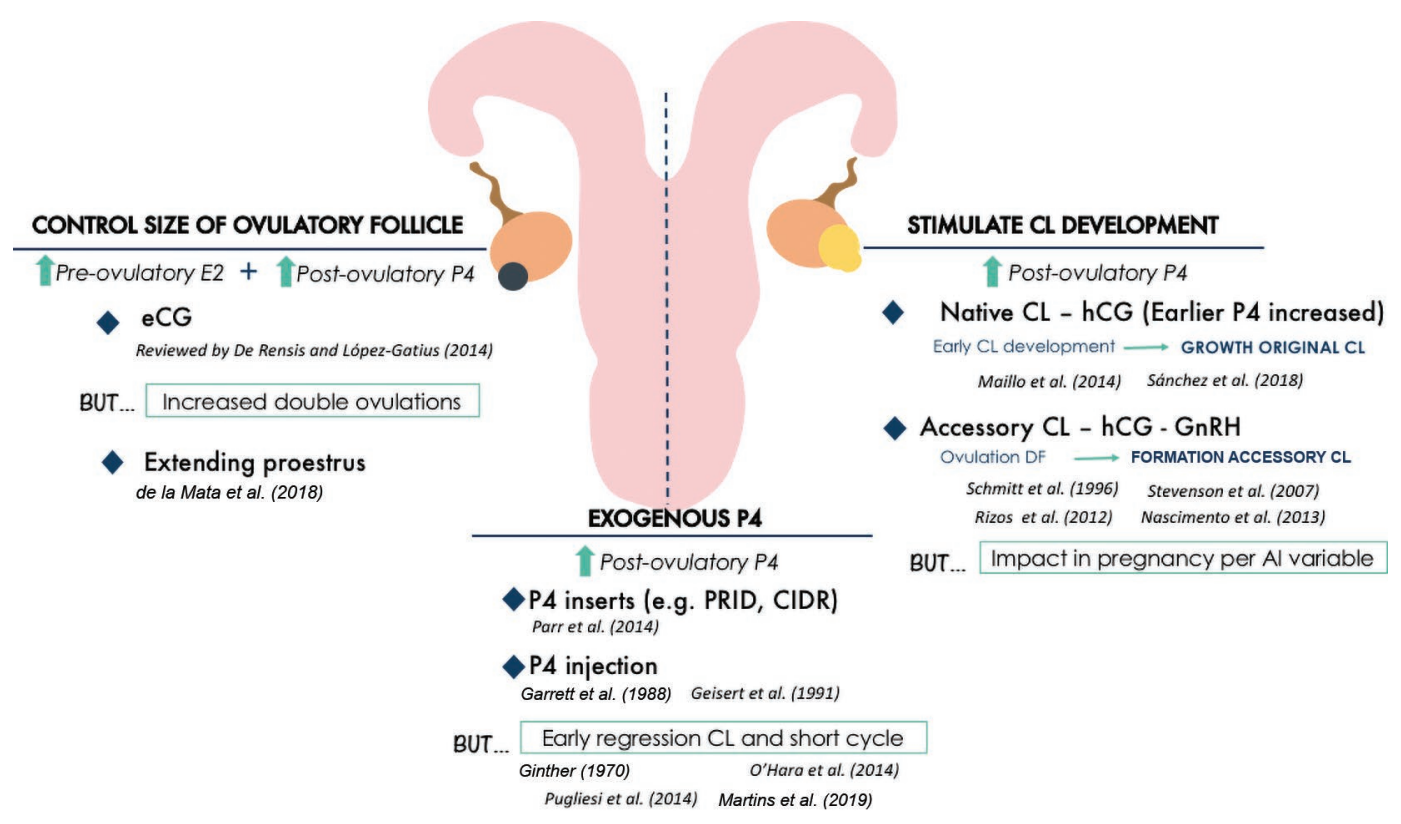

Figure 1. Approaches to increasing peripheral concentrations of progesterone (P4) after AI include (1) those that increase the function of the existing corpus luteum [CL; e.g., strategies that promote growth of the dominant follicle before ovulation, resulting in a larger CL; or luteotrophic treatments that stimulate CL development, such as administration of human chorionic gonadotropin (hCG)]; (2) those that induce ovulation of a dominant follicle and formation of accessory CL (e.g., hCG or GnRH administration); or (3) those that supplement progesterone directly (e.g., via injection or intravaginal devices). CIDR = controlled internal drug-release device; PRID = progesterone-releasing intravaginal device. $\mathrm{E} 2$ = estradiol; $\mathrm{eCG}=$ equine chorionic gonadotropin; $\mathrm{DF}=$ dominant follicle.

\section{REFERENCES}

Akison, L. K., and R. L. Robker. 2012. The critical roles of progesterone receptor (PGR) in ovulation, oocyte developmental competence and oviductal transport in mammalian reproduction. Reprod. Domest. Anim. 47(Suppl. 4):288-296. https://doi.org/10 .1111/j.1439-0531.2012.02088.x.

Aparicio, I. M., M. Garcia-Herreros, L. C. O'Shea, C. Hensey, P. Lonergan, and T. Fair. 2011. Expression, regulation, and function of progesterone receptors in bovine cumulus oocyte complexes during in vitro maturation. Biol. Reprod. 84:910-921. https://doi.org/10 .1095/biolreprod.110.087411.

Barnwell, C. V., P. W. Farin, C. M. Ashwell, W. T. Farmer, S. P. Galphin Jr., and C. E. Farin. 2016. Differences in mRNA populations of short and long bovine conceptuses on Day 15 of gestation. Mol. Reprod. Dev. 83:424-441. https://doi.org/10.1002/mrd.22640.

Bauersachs, S., S. E. Ulbrich, H. D. Reichenbach, M. Reichenbach, M. Buttner, H. H. Meyer, T. E. Spencer, M. Minten, G. Sax, G. Winter, and E. Wolf. 2012. Comparison of the effects of early pregnancy with human interferon, alpha 2 (IFNA2), on gene expression in bovine endometrium. Biol. Reprod. 86:46. https://doi.org/10 $.1095 /$ biolreprod.111.094771.

Bazer, F. W., X. Wang, G. A. Johnson, and G. Wu. 2015. Select nutrients and their effects on conceptus development in mammals. Anim. Nutr. 1:85-95. https://doi.org/10.1016/j.aninu.2015.07.005.

Bazer, F. W., G. Wu, T. E. Spencer, G. A. Johnson, R. C. Burghardt, and K. Bayless. 2010. Novel pathways for implantation and establishment and maintenance of pregnancy in mammals. Mol. Hum. Reprod. 16:135-152. https://doi.org/10.1093/molehr/gap095.

Beltman, M. E., J. F. Roche, P. Lonergan, N. Forde, and M. A. Crowe. 2009. Evaluation of models to induce low progesterone during the early luteal phase in cattle. Theriogenology 72:986-992. https:// doi.org/10.1016/j.theriogenology.2009.06.018.

Berg, D. K., J. van Leeuwen, S. Beaumont, M. Berg, and P. L. Pfeffer. 2010. Embryo loss in cattle between Days 7 and 16 of preg- nancy. Theriogenology 73:250-260. https://doi.org/10.1016/j .theriogenology.2009.09.005.

Binelli, M., S. C. Scolari, G. Pugliesi, V. Van Hoeck, A. M. GonellaDiaza, S. C. Andrade, G. R. Gasparin, and L. L. Coutinho. 2015. The transcriptome signature of the receptive bovine uterus determined at early gestation. PLoS One 10:e0122874. https://doi.org/ 10.1371/journal.pone.0122874.

Bisinotto, R. S., I. J. Lean, W. W. Thatcher, and J. E. Santos. 2015. Meta-analysis of progesterone supplementation during timed artificial insemination programs in dairy cows. J. Dairy Sci. 98:24722487. https://doi.org/10.3168/jds.2014-8954.

Brooks, K., G. Burns, and T. E. Spencer. 2014. Conceptus elongation in ruminants: Roles of progesterone, prostaglandin, interferon tau and cortisol. J. Anim. Sci. Biotechnol. 5:53. https://doi.org/10 $.1186 / 2049-1891-5-53$.

Bylander, A., L. Gunnarsson, R. Shao, H. Billig, and D. G. Larsson. 2015. Progesterone-mediated effects on gene expression and oocyte-cumulus complex transport in the mouse fallopian tube. Reprod. Biol. Endocrinol. 13:40. https://doi.org/10.1186/s12958 $-015-0038-8$.

Carter, F., N. Forde, P. Duffy, M. Wade, T. Fair, M. A. Crowe, A. C Evans, D. A. Kenny, J. F. Roche, and P. Lonergan. 2008. Effect of increasing progesterone concentration from Day 3 of pregnancy on subsequent embryo survival and development in beef heifers. Reprod. Fertil. Dev. 20:368-375. https://doi.org/10.1071/RD07204.

Carter, F., F. Rings, S. Mamo, M. Holker, A. Kuzmany, U. Besenfelder, V. Havlicek, J. P. Mehta, D. Tesfaye, K. Schellander, and P. Lonergan. 2010. Effect of elevated circulating progesterone concentration on bovine blastocyst development and global transcriptome following endoscopic transfer of in vitro produced embryos to the bovine oviduct. Biol. Reprod. 83:707-719. https://doi.org/ 10.1095/biolreprod.109.082354.

Carvalho, P. D., V. G. Santos, J. O. Giordano, M. C. Wiltbank, and P. M. Fricke. 2018. Development of fertility programs to achieve high 21-day pregnancy rates in high-producing dairy cows. The- 
riogenology 114:165-172. https://doi.org/10.1016/j.theriogenology 2018.03.037.

Christie, W. B., R. Newcomb, and L. E. Rowson. 1979. Embryo survival in heifers after transfer of an egg to the uterine horn contralateral to the corpus luteum and the effect of treatments with progesterone or hCG on pregnancy rates. J. Reprod. Fertil. 56:701-706. https://doi.org/10.1530/jrf.0.0560701.

Clemente, M., J. de La Fuente, T. Fair, A. Al Naib, A. GutierrezAdan, J. F. Roche, D. Rizos, and P. Lonergan. 2009. Progesterone and conceptus elongation in cattle: A direct effect on the embryo or an indirect effect via the endometrium? Reproduction 138:507517. https://doi.org/10.1530/REP-09-0152.

Cole, J. B., and P. M. VanRaden. 2018. Possibilities in an age of genomics: The future of selection indices. J. Dairy Sci. 101:36863701. https://doi.org/10.3168/jds.2017-13335.

Crisman, R. O., L. E. McDonald, and C. E. Wallace. 1980. Oviduct (uterine tube) transport of ova in the cow. Am. J. Vet. Res. 41:645-647.

de la Mata, J. J., R. Núñez-Olivera, F. Cuadro, D. Bosolasco, V. de Brun, A. Meikle, G. A. Bó, and A. Menchaca. 2018. Effects of extending the length of pro-oestrus in an oestradiol- and progesterone-based oestrus synchronisation program on ovarian function, uterine environment and pregnancy establishment in beef heifers. Reprod. Fertil. Dev. 30:1541-1552. https://doi.org/10.1071/ RD17473.

De Rensis, F., and F. López-Gatius. 2014. Use of equine chorionic gonadotropin to control reproduction of the dairy cow: A review. Reprod. Domest. Anim. 49:177-182. https://doi.org/10.1111/rda .12268 .

De Vries, A. 2006. Economic value of pregnancy in dairy cattle. J. Dairy Sci. 89:3876-3885. https://doi.org/10.3168/jds.S0022 -0302(06)72430-4.

Del Campo, M. R., R. F. Rowe, D. Chaichareon, and O. J. Ginther. 1983. Effect of the relative locations of embryo and corpus luteum on embryo survival in cattle. Reprod. Nutr. Dev. 23(Suppl. 2A):303-308. https://doi.org/10.1051/rnd:19830214.

Denicol, A. C., G. Lopes Jr., L. G. Mendonça, F. A. Rivera, F. Guagnini, R. V. Perez, J. R. Lima, R. G. S. Bruno, J. E. P. Santos, and R. C. Chebel. 2012. Low progesterone concentration during the development of the first follicular wave reduces pregnancy per insemination of lactating dairy cows. J. Dairy Sci. 95:1794-1806. https://doi.org/10.3168/jds.2011-4650.

Dieleman, S. J., M. M. Bevers, J. Poortman, and H. T. van Tol. 1983. Steroid and pituitary hormone concentrations in the fluid of preovulatory bovine follicles relative to the peak of LH in the peripheral blood. J. Reprod. Fertil. 69:641-649. https://doi.org/10.1530/ jrf.0.0690641.

Diskin, M. G., and D. G. Morris. 2008. Embryonic and early foetal losses in cattle and other ruminants. Reprod. Domest. Anim. 43(Suppl. 2):260-267. https://doi.org/10.1111/j.1439-0531.2008 .01171.x.

Dorniak, P., T. H. Welsh Jr., F. W. Bazer, and T. E. Spencer. 2013. Cortisol and interferon tau regulation of endometrial function and conceptus development in female sheep. Endocrinology 154:931941. https://doi.org/10.1210/en.2012-1909.

Fair, T. 2015. The contribution of the maternal immune system to the establishment of pregnancy in cattle. Front. Immunol. 6:7. https:/ /doi.org/10.3389/fimmu.2015.00007.

Faulkner, S., G. Elia, P. O' Boyle, M. Dunn, and D. Morris. 2013. Composition of the bovine uterine proteome is associated with stage of cycle and concentration of systemic progesterone. Proteomics 13:3333-3353. https://doi.org/10.1002/pmic.201300204.

Fléchon, J. E., M. Guillomot, M. Charlier, B. Fléchon, and J. Martal. 1986. Experimental studies on the elongation of the ewe blastocyst. Reprod. Nutr. Dev. 26:1017-1024. https://doi.org/10.1051/ rnd:19860609.

Forde, N., F. W. Bazer, T. E. Spencer, and P. Lonergan. 2015. 'Conceptualizing' the endometrium: Identification of conceptus-derived proteins during early pregnancy in cattle. Biol. Reprod. 92:156. https://doi.org/10.1095/biolreprod.115.129296.
Forde, N., M. E. Beltman, G. B. Duffy, P. Duffy, J. P. Mehta, P. O'Gaora, J. F. Roche, P. Lonergan, and M. A. Crowe. 2011a. Changes in the endometrial transcriptome during the bovine estrous cycle: Effect of low circulating progesterone and consequences for conceptus elongation. Biol. Reprod. 84:266-278. https://doi .org/10.1095/biolreprod.110.085910.

Forde, N., F. Carter, T. Fair, M. A. Crowe, A. C. Evans, T. E. Spencer, F. W. Bazer, R. McBride, M. P. Boland, P. O'Gaora, P. Lonergan, and J. F. Roche. 2009. Progesterone-regulated changes in endometrial gene expression contribute to advanced conceptus development in cattle. Biol. Reprod. 81:784-794. https://doi.org/ 10.1095/biolreprod.108.074336.

Forde, N., F. Carter, T. E. Spencer, F. W. Bazer, O. Sandra, N. Mansouri-Attia, L. A. Okumu, P. A. McGettigan, J. P. Mehta, R. McBride, P. O'Gaora, J. F. Roche, and P. Lonergan. 2011b. Conceptus-induced changes in the endometrial transcriptome: How soon does the cow know she is pregnant? Biol. Reprod. 85:144-156. https://doi.org/10.1095/biolreprod.110.090019.

Forde, N., and P. Lonergan. 2017. Interferon-tau and fertility in ruminants. Reproduction 154:F33-F43. https://doi.org/10.1530/REP $-17-0432$

Forde, N., P. A. McGettigan, J. P. Mehta, L. O'Hara, S. Mamo, F. W. Bazer, T. E. Spencer, and P. Lonergan. 2014. Proteomic analysis of uterine fluid during the pre-implantation period of pregnancy in cattle. Reproduction 147:575-587. https://doi.org/10.1530/REP $-13-0010$.

Forde, N., J. P. Mehta, M. Minten, M. A. Crowe, J. F. Roche, T. E. Spencer, and P. Lonergan. 2012. Effects of low progesterone on the endometrial transcriptome in cattle. Biol. Reprod. 87:124. https:/ /doi.org/10.1095/biolreprod.112.103424.

Garrett, J. E., R. D. Geisert, M. T. Zavy, and G. L. Morgan. 1988 Evidence for maternal regulation of early conceptus growth and development in beef cattle. J. Reprod. Fertil. 84:437-446. https:// doi.org/10.1530/jrf.0.0840437.

Gegenfurtner, K., T. Fröhlich, F. Flenkenthaler, M. Kösters, S. Fritz, O. Desnoës, D. L. Bourhis, P. Salvetti, O. Sandra, G. Charpigny, P. Mermillod, P. Lonergan, E. Wolf, and G. J. Arnold. 2020. Genetic merit for fertility alters the bovine uterine luminal fluid proteome. Biol. Reprod. 102:730-739. https://doi.org/10.1093/biolre/ioz216.

Geisert, R. D., T. C. Fox, G. L. Morgan, M. E. Wells, R. P. Wettemann, and M. T. Zavy. 1991. Survival of bovine embryos transferred to progesterone-treated asynchronous recipients. J. Reprod. Fertil. 92:475-482. https://doi.org/10.1530/jrf.0.0920475.

Ginther, O. J. 1970. Effect of progesterone on length of estrous cycle in cattle. Am. J. Vet. Res. 31:493-496.

Gray, C. A., K. M. Taylor, W. S. Ramsey, J. R. Hill, F. W. Bazer, F. F. Bartol, and T. E. Spencer. 2001. Endometrial glands are required for preimplantation conceptus elongation and survival. Biol. Reprod. 64:1608-1613. https://doi.org/10.1095/biolreprod64 .6.1608.

Hansen, P. J. 2010. Medawar redux-An overview on the use of farm animal models to elucidate principles of reproductive immunology. Am. J. Reprod. Immunol. 64:225-230. https://doi.org/10.1111/j $.1600-0897.2010 .00900 . x$.

Hansen, P. J., F. W. Bazer, and E. C. Segerson Jr.. 1986. Skin graft survival in the uterine lumen of ewes treated with progesterone. Am. J. Reprod. Immunol. Microbiol. 12:48-54. https://doi.org/10 $.1111 /$ j.1600-0897.1986.tb00062.x.

Hugentobler, S. A., J. M. Sreenan, P. G. Humpherson, H. J. Leese, M. G. Diskin, and D. G. Morris. 2010. Effects of changes in the concentration of systemic progesterone on ions, amino acids and energy substrates in cattle oviduct and uterine fluid and blood. Reprod. Fertil. Dev. 22:684-694. https://doi.org/10.1071/RD09129.

Inskeep, E. K. 2004. Preovulatory, postovulatory, and post maternal recognition effects of concentrations of progesterone on embryonic survival in the cow. J. Anim. Sci. 82(Suppl.):E24-E39. https://doi .org/10.2527/2004.8213_supplE24x.

Larson, J. E., R. L. Krisher, and G. C. Lamb. 2011. Effects of supplemental progesterone on the development, metabolism and blastocyst cell number of bovine embryos produced in vitro. Reprod. Fertil. Dev. 23:311-318. https://doi.org/10.1071/RD10106. 
Lawson, R. A., and L. P. Cahill. 1983. Modification of the embryomaternal relationship in ewes by progesterone treatment early in the oestrous cycle. J. Reprod. Fertil. 67:473-475. https://doi.org/ $10.1530 /$ jrf.0.0670473.

Ledgard, A. M., M. C. Berg, W. H. McMillan, G. Smolenski, and A. J. Peterson. 2012. Effect of asynchronous transfer on bovine embryonic development and relationship with early cycle uterine proteome profiles. Reprod. Fertil. Dev. 24:962-972. https://doi.org/ 10.1071/RD11225.

Li, Q., F. Jimenez-Krassel, A. Bettegowda, J. J. Ireland, and G. W. Smith. 2007. Evidence that the preovulatory rise in intrafollicular progesterone may not be required for ovulation in cattle. J. Endocrinol. 192:473-483. https://doi.org/10.1677/JOE-06-0020.

Lonergan, P. 2011. Influence of progesterone on oocyte quality and embryo development in cows. Theriogenology 76:1594-1601. https: //doi.org/10.1016/j.theriogenology.2011.06.012.

Lonergan, P., and N. Forde. 2014. Maternal-embryo interaction leading up to the initiation of implantation of pregnancy in cattle. Animal 8(Suppl. 1):64-69. https://doi.org/10.1017/S1751731114000470.

Lonergan, P., and N. Forde. 2015. The role of progesterone in maternal recognition of pregnancy in domestic ruminants. Adv. Anat. Embryol. Cell Biol. 216:87-104. https://doi.org/10.1007/978-3-319 $-15856-3 \_6$.

Lucy, M. C. 2019. Selection for fertility in the modern dairy cow-Current status and future direction for genetic selection. J. Dairy Sci. 102:3706-3721. https://doi.org/10.3168/jds.2018-15544.

Maillo, V., P. Duffy, L. O'Hara, C. de Frutos, A. K. Kelly, P. Lonergan, and D. Rizos. 2014. Effect of hCG administration during corpus luteum establishment on subsequent corpus luteum development and circulating progesterone concentrations in beef heifers. Reprod. Fertil. Dev. 26:367-374. https://doi.org/10.1071/RD12353.

Majewski, A. C., and P. J. Hansen. 2002. Progesterone inhibits rejection of xenogeneic transplants in the sheep uterus. Horm. Res. 58:128-135. https://doi.org/10.1159/000063578.

Martins, T., G. Pugliesi, M. Sponchiado, B. O. Cardoso, K. R. da Silva, E. C. C. Celeghini, and M. Binelli. 2019. Supplementation with long-acting progesterone in early diestrus in beef cattle: II. Relationships between follicle growth dynamics and luteolysis. Domest. Anim. Endocrinol. 68:1-10. https://doi.org/10.1016/j.domaniend .2018.12.004

Miglior, F., A. Fleming, F. Malchiodi, L. F. Brito, P. Martin, and C. F. Baes. 2017. A 100-Year Review: Identification and genetic selection of economically important traits in dairy cattle. J. Dairy Sci. 100:10251-10271. https://doi.org/10.3168/jds.2017-12968.

Mullen, M. P., G. Elia, M. Hilliard, M. H. Parr, M. G. Diskin, A. C. Evans, and M. A. Crowe. 2012. Proteomic characterization of histotroph during the preimplantation phase of the estrous cycle in cattle. J. Proteome Res. 11:3004-3018. https://doi.org/10.1021/ pr300144q.

Nascimento, A. B., R. W. Bender, A. H. Souza, H. Ayres, R. R. Araujo, J. N. Guenther, R. Sartori, and M. C. Wiltbank. 2013. Effect of treatment with human chorionic gonadotropin on day 5 after timed artificial insemination on fertility of lactating dairy cows. J. Dairy Sci. 96:2873-2882. https://doi.org/10.3168/jds.2012-5895.

Nasser, L. F., M. F. Sá Filho, E. L. Reis, C. R. Rezende, R. J. Mapletoft, G. A. Bó, and P. S. Baruselli. 2011. Exogenous progesterone enhances ova and embryo quality following superstimulation of the first follicular wave in Nelore (Bos indicus) donors. Theriogenology 76:320-327. https://doi.org/10.1016/j.theriogenology.2011.02.009.

Niles, A. M., H. P. Fricke, P. D. Carvalho, M. C. Wiltbank, L. L. Hernandez, and P. M. Fricke. 2019. Effect of treatment with human chorionic gonadotropin 7 days after artificial insemination or at the time of embryo transfer on reproductive outcomes in nulliparous Holstein heifers. J. Dairy Sci. 102:2593-2606. https://doi.org/ 10.3168/jds.2018-15588.

Niswender, G. D. 2002. Molecular control of luteal secretion of progesterone. Reproduction 123:333-339. https://doi.org/10.1530/rep .0 .1230333 .

O'Hara, L., N. Forde, A. K. Kelly, and P. Lonergan. 2014. Effect of bovine blastocyst size at embryo transfer on day 7 on conceptus length on day 14: Can supplementary progesterone rescue small embryos? Theriogenology 81:1123-1128. https://doi.org/10.1016/j theriogenology.2014.01.041.

O'Hara, L., S. Scully, V. Maillo, A. K. Kelly, P. Duffy, F. Carter, N. Forde, D. Rizos, and P. Lonergan. 2012. Effect of follicular aspiration just before ovulation on corpus luteum characteristics, circulating progesterone concentrations and uterine receptivity in single-ovulating and superstimulated heifers. Reproduction 143:673-682. https://doi.org/10.1530/REP-11-0505.

Okumu, L. A., N. Forde, A. G. Fahey, E. Fitzpatrick, J. F. Roche, M. A. Crowe, and P. Lonergan. 2010. The effect of elevated progesterone and pregnancy status on mRNA expression and localisation of progesterone and oestrogen receptors in the bovine uterus. Reproduction 140:143-153. https://doi.org/10.1530/REP-10-0113.

Oliveira, L. J., and P. J. Hansen. 2008. Deviations in populations of peripheral blood mononuclear cells and endometrial macrophages in the cow during pregnancy. Reproduction 136:481-490. https:// doi.org/10.1530/REP-08-0218.

Ott, T. L. 2020. Immunological detection of pregnancy: Evidence for systemic immune modulation during early pregnancy in ruminants. Theriogenology. https://doi.org/10.1016/j.theriogenology 2020.04.010.

Padua, M. B., S. Tekin, T. E. Spencer, and P. J. Hansen. 2005. Actions of progesterone on uterine immunosuppression and endometrial gland development in the uterine gland knockout (UGKO) ewe. Mol. Reprod. Dev. 71:347-357. https://doi.org/10.1002/mrd .20301 .

Parr, M. H., M. A. Crowe, P. Lonergan, A. C. Evans, D. Rizos, and M. G. Diskin. 2014. Effect of exogenous progesterone supplementation in the early luteal phase post-insemination on pregnancy per artificial insemination in Holstein-Friesian cows. Anim. Reprod. Sci. 150:7-14. https://doi.org/10.1016/j.anireprosci.2014.08.008.

Pope, W. F., R. R. Maurer, and F. Stormshak. 1982. Distribution of progesterone in the uterus, broad ligament, and uterine arteries of beef cows. Anat. Rec. 203:245-249. https://doi.org/10.1002/ar .1092030206.

Pugliesi, G., M. L. Oliveria, S. C. Scolari, E. Lopes, F. V. Pinaffi, B. T. Miagawa, Y. N. Paiva, J. R. Maio, G. P. Nogueira, and M. Binelli. 2014. Corpus luteum development and function after supplementation of long-acting progesterone during the early luteal phase in beef cattle. Reprod. Domest. Anim. 49:85-91. https://doi.org/10 $.1111 /$ rda. 12231 .

Pursley, J. R., and J. P. Martins. 2011. Impact of circulating concentrations of progesterone and antral age of the ovulatory follicle on fertility of high-producing lactating dairy cows. Reprod. Fertil. Dev. 24:267-271. https://doi.org/10.1071/RD11917.

Randi, F., B. Fernandez-Fuertes, M. McDonald, N. Forde, A. K. Kelly, H. Bastos Amorin, E. Muniz de Lima, F. Morotti, M. Marcondes Seneda, and P. Lonergan. 2016. Asynchronous embryo transfer as a tool to understand embryo-uterine interaction in cattle: Is a large conceptus a good thing? Reprod. Fertil. Dev. 28:1999-2006. https: //doi.org/10.1071/RD15195.

Rivera, F. A., L. G. Mendonça, G. Lopes Jr., J. E. Santos, R. V. Perez, M. Amstalden, A. Correa-Calderón, and R. C. Chebel. 2011. Reduced progesterone concentration during growth of the first follicular wave affects embryo quality but has no effect on embryo survival post transfer in lactating dairy cows. Reproduction 141:333-342. https://doi.org/10.1530/REP-10-0375.

Rizos, D., S. Scully, A. K. Kelly, A. D. Ealy, R. Moros, P. Duffy, A. Al Naib, N. Forde, and P. Lonergan. 2012. Effects of human chorionic gonadotrophin administration on day 5 after oestrus on corpus luteum characteristics, circulating progesterone and conceptus elongation in cattle. Reprod. Fertil. Dev. 24:472-481. https://doi.org/ 10.1071/RD11139.

Rodríguez-Alonso, B., J. M. Sánchez, M. Hamdi, M. McDonald, V. Havlicek, U. Besenfelder, P. Lonergan, and D. Rizos. 2020. Asynchrony between the early embryo and the reproductive tract affects subsequent embryo development in cattle. Reprod. Fertil. Dev. 32:564. https://doi.org/10.1071/RD19360.

Saint-Dizier, M., O. Sandra, S. Ployart, M. Chebrout, and F. Constant. 2012. Expression of nuclear progesterone receptor and progesterone receptor membrane components 1 and 2 in the oviduct 
of cyclic and pregnant cows during the post-ovulation period. Reprod. Biol. Endocrinol. 10:76. https://doi.org/10.1186/1477-7827 $-10-76$.

Sánchez, J. M., D. J. Mathew, S. K. Behura, C. Passaro, G. Charpigny, S. T. Butler, T. E. Spencer, and P. Lonergan. 2019a. Bovine endometrium responds differentially to age-matched short and long conceptuses. Biol. Reprod. 101:26-39. https://doi.org/10.1093/ biolre/ioz060.

Sánchez, J. M., C. Passaro, N. Forde, J. A. Browne, S. K. Behura, B. Fernández-Fuertes, D. J. Mathew, A. K. Kelly, S. T. Butler, T. E. Spencer, and P. Lonergan. 2019b. Do differences in the endometrial transcriptome between uterine horns ipsilateral and contralateral to the corpus luteum influence conceptus growth to day 14 in cattle? Biol. Reprod. 100:86-100. https://doi.org/10.1093/ biolre/ioy185.

Sánchez, J. M., F. Randi, C. Passaro, D. J. Mathew, S. T. Butler, and P. Lonergan. 2018. Effect of human chorionic gonadotrophin administration 2 days after insemination on progesterone concentration and pregnancy per artificial insemination in lactating dairy cows. J. Dairy Sci. 101:6556-6567. https://doi.org/10.3168/ jds.2017-14058.

Sangsritavong, S., D. K. Combs, R. Sartori, L. E. Armentano, and M. C. Wiltbank. 2002. High feed intake increases liver blood flow and metabolism of progesterone and estradiol-17beta in dairy cattle. J. Dairy Sci. 85:2831-2842. https://doi.org/10.3168/jds.S0022 -0302(02)74370-1.

Sartori, R., M. R. Bastos, and M. C. Wiltbank. 2010. Factors affecting fertilisation and early embryo quality in single- and superovulated dairy cattle. Reprod. Fertil. Dev. 22:151-158. https://doi.org/10 .1071/RD09221.

Satterfield, M. C., F. W. Bazer, and T. E. Spencer. 2006. Progesterone regulation of preimplantation conceptus growth and galectin 15 (LGALS15) in the ovine uterus. Biol. Reprod. 75:289-296. https:/ /doi.org/10.1095/biolreprod.106.052944.

Schmitt, E. J., T. Diaz, M. Drost, and W. W. Thatcher. 1996. Use of a gonadotropin-releasing hormone agonist or human chorionic gonadotropin for timed insemination in cattle. J. Anim. Sci. 74:10841091. https://doi.org/10.2527/1996.7451084x.

Shalloo, L., A. Cromie, and N. McHugh. 2014. Effect of fertility on the economics of pasture-based dairy systems. Animal 8(Suppl. 1):222-231. https://doi.org/10.1017/S1751731114000615.

Shorten, P. R., A. M. Ledgard, M. Donnison, P. L. Pfeffer, R. M. McDonald, and D. K. Berg. 2018. A mathematical model of the interaction between bovine blastocyst developmental stage and progesterone-stimulated uterine factors on differential embryonic development observed on Day 15 of gestation. J. Dairy Sci. 101:736-751. https://doi.org/10.3168/jds.2017-12845.

Simintiras, C. A., J. M. Sánchez, M. McDonald, and P. Lonergan. 2019a. Progesterone alters the bovine uterine fluid lipidome during the period of elongation. Reproduction 157:399-411. https://doi .org/10.1530/REP-18-0615.

Simintiras, C. A., J. M. Sánchez, M. McDonald, and P. Lonergan. $2019 \mathrm{~b}$. The influence of progesterone on bovine uterine fluid energy, nucleotide, vitamin, cofactor, peptide, and xenobiotic composition during the conceptus elongation-initiation window. Sci. Rep. 9:7716. https://doi.org/10.1038/s41598-019-44040-6.
Simintiras, C. A., J. M. Sánchez, M. McDonald, T. Martins, M. Binelli, and P. Lonergan. 2019c. Biochemical characterization of progesterone-induced alterations in bovine uterine fluid amino acid and carbohydrate composition during the conceptus elongation window. Biol. Reprod. 100:672-685. https://doi.org/10.1093/ biolre/ioy 234 .

Spencer, T. E., N. Forde, and P. Lonergan. 2016. The role of progesterone and conceptus-derived factors in uterine biology during early pregnancy in ruminants. J. Dairy Sci. 99:5941-5950. https://doi .org/10.3168/jds.2015-10070.

Steinhauser, C. B., M. Landers, L. Myatt, R. C. Burghardt, J. L. Vallet, F. W. Bazer, and G. A. Johnson. 2016. Fructose synthesis and transport at the uterine-placental interface of pigs: Cell-specific localization of SLC2A5, SLC2A8, and components of the polyol pathway. Biol. Reprod. 95:108. https://doi.org/10.1095/biolreprod .116.142174.

Stevenson, J. S., M. A. Portaluppi, D. E. Tenhouse, A. Lloyd, D. R. Eborn, S. Kacuba, and J. M. DeJarnette. 2007. Interventions after artificial insemination: conception rates, pregnancy survival, and ovarian responses to gonadotropin-releasing hormone, human chorionic gonadotropin, and progesterone. J. Dairy Sci. 90:331-340. https://doi.org/10.3168/jds.S0022-0302(07)72634-6.

Szekeres-Bartho, J. 2018. The role of progesterone in feto-maternal immunological cross talk. Med. Princ. Pract. 27:301-307. https:// doi.org/10.1159/000491576.

Takahashi, H., S. Haneda, M. Kayano, and M. Matsui. 2016. Differences in progesterone concentrations and mRNA expressions of progesterone receptors in bovine endometrial tissue between the uterine horns ipsilateral and contralateral to the corpus luteum. J. Vet. Med. Sci. 78:613-618. https://doi.org/10.1292/jvms.15-0366.

Wiltbank, M. C., G. M. Baez, A. Garcia-Guerra, M. Z. Toledo, P. L. Monteiro, L. F. Melo, J. C. Ochoa, J. E. Santos, and R. Sartori. 2016. Pivotal periods for pregnancy loss during the first trimester of gestation in lactating dairy cows. Theriogenology 86:239-253. https://doi.org/10.1016/j.theriogenology.2016.04.037.

Wiltbank, M. C., A. H. Souza, P. D. Carvalho, R. W. Bender, and A. B. Nascimento. 2011. Improving fertility to timed artificial insemination by manipulation of circulating progesterone concentrations in lactating dairy cattle. Reprod. Fertil. Dev. 24:238-243. https:// doi.org/10.1071/RD11913.

Wiltbank, M. C., A. H. Souza, P. D. Carvalho, A. P. Cunha, J. O. Giordano, P. M. Fricke, G. M. Baez, and M. G. Diskin. 2014. Physiological and practical effects of progesterone on reproduction in dairy cattle. Animal 8(Suppl. 1):70-81. https://doi.org/10 $.1017 /$ S1751731114000585.

Yan, L., R. Robinson, Z. Shi, and G. Mann. 2016. Efficacy of progesterone supplementation during early pregnancy in cows: A meta-analysis. Theriogenology 85:1390-1398.e1. https://doi.org/ 10.1016/j.theriogenology.2015.12.027.

\section{ORCIDS}

P. Lonergan (1) https://orcid.org/0000-0001-5598-5044

J. M. Sánchez @ https://orcid.org/0000-0003-3889-2342 